\title{
PERBANDINGAN RISK DAN RETURN INVESTASI PADA EMAS, SAHAM DAN REKSADANA DALAM MENENTUKAN KEPUTUSAN INVESTASI
}

\author{
Wirawan ED Radianto \\ Citra Ayuningtyas \\ Universitas Ciputra Surabaya \\ Email:wradianto@gmail.com
}

Artikel diterima: 15 Januari 2010

Revisi terakhir: 17 Februari 2010

\begin{abstract}
The purpose of this study is to investigate whether there are differences in risk and return of investment in investment instruments that investigated the third is gold, $L Q$ 45 index and Mutual Funds. Comparative risk and return is to know where the most profitable instruments so that the right to choose in making investment decisions. The sample used is the price of gold, $L Q 45$ index and NAV shares of mutual funds during the period from 1997 until 2009. One Way ANOVA is used in this study. The results of this study as follows. There is a significant difference of risk and return among gold, mutual fund, and LQ 45 index. Finally it can be concluded that gold is the most profitable investment instruments, it is because the smaller the coefficient of variation, the more profitable an investment.
\end{abstract}

Keywords: risk, return, the coefficient of variation, gold, $L Q 45$ index, mutual fund shares.

\section{PENDAHULUAN}

Kondisi perekonomian yang selalu berubah dan berkembang, membuat masyarakat seharusnya cermat dalam mengalokasikan kekayaannya. Terlebih lagi tidak dapat dipungkiri bahwa setiap tahun akan terjadi inflasi, yaitu kenaikan umum sebagian besar harga barang dan jasa di pasaran yang menyebabkan turunnya daya beli mata uang terhadap barang atau jasa tersebut.

Salah satu alternatif investasi yang sedang gencar diperbincangkan adalah investasi pada komoditas emas. Emas merupakan salah satu logam mulia yang memiliki nilai cukup tinggi, baik dari segi harga maupun kegunaannya. Logam mulia ini sering digunakan sebagai media berhias, investasi, prestige sekaligus sering digunakan sebagai lambang sesuatu hal yang bersifat sakral, seperti acara pertunangan dan pernikahan.

Dengan nilai emas yang tinggi, membuat banyak alternatif untuk mengembangkan bisnis ini, mulai dari perusahaan perhiasan emas, supplier perhiasan 
emas, outlet retail perhiasan emas, pegadaian emas, hingga para kolektor emas. Fenomena yang diambil untuk melatarbelakangi penelitian ini adalah salah satu kasus yang terjadi pada outlet retail perhiasan emas yang dimiliki peneliti.

Menurut Palaloi (2006), emas merupakan salah satu jenis investasi yang tidak terkena dampak inflasi, sekaligus dapat dijadikan sebagai pengganti alat lindung nilai (hedging) terhadap fluktuasi mata uang rupiah. Emas juga digunakan sebagai cadangan dalam sistem stabilitas moneter setiap negara. Nilai emas dimanfaatkan sebagai sarana portofolio saat mengelola cadangan devisa negara. Saat cadangan devisa mengalami banyak perubahan, nilai emas masih tetap stabil sehingga dapat mengurangi kerugian negara akibat naik turunnya cadangan devisa dan nilai keuangan.

Penelitian ini bertujuan untuk menginvestigasi perbedaan dan perbandingan risk dan return emas apabila dibandingkan dengan beberapa instrumen investasi yang lain. Selain emas, terdapat sarana investasi lain seperti properti, saham, reksadana maupun valuta asing. Masing-masing dari sarana investasi ini memiliki tingkat pengembalian maupun risiko yang berbeda-beda. Untuk mengetahui instrumen investasi manakah yang memiliki tingkat keuntungan lebih besar, dilakukan dengan cara membandingkan Risk dan Return antara emas dengan instrumen investasi yang lain.

Dalam penelitian ini, saham dan reksadana dipilih untuk dibandingkan tingkat risk dan returnnya terhadap emas. Ketiga instrumen investasi ini dapat dikategorikan dalam jenis investasi jangka menengah hingga jangka panjang. Selain itu, masingmasing dari instrumen ini memiliki pasar yang jelas serta lembaga-lembaga yang mengelola perdagangan ketiga instrumen investasi tersebut.

Ketiga instrumen investasi ini dipilih juga dikarenakan ketiga instrumen investasi ini merupakan instrumen investasi paling diminati masyarakat (SWA, 4 Januari 2007). Dalam artikel ini dituliskan bahwa saham menempati posisi pertama sebagai instrumen investasi paling diminati disusul oleh reksadana, kemudian obligasi dan selanjutnya pada posisi keempat adalah bursa dan komoditi berjangka, serta yang terakhir adalah properti.

Untuk sarana investasi saham, peneliti memilih indeks LQ 45 karena indeks ini merupakan kumpulan saham unggulan yang aktif diperdagangkan di BEI. Sedangkan untuk investasi pada reksadana, peneliti memilih reksadana saham sebagai pembanding investasi emas. Hal ini dikarenakan reksadana saham merupakan jenis investasi reksadana jangka menengah hingga panjang yaitu antara 4 sampai 5 tahun. Selain itu reksadana saham merupakan jenis investasi agresif dengan imbal hasil dan risiko yang cukup berimbang. Berikut ini adalah grafik jenis investasi reksadana dilihat dari imbal hasil, risiko, dan jangka waktu investasi.

\section{KAJIAN PUSTAKA}

\section{Penelitian Terdahulu}

Riessa (2006) melakukan penelitian untuk membahas perbandingan risk dan return pada saham LQ 45 dan Jakarta Islamic Index dengan Pendekatan CAPM. 
Sebelum memutuskan berinvestasi saham, investor akan melihat return yang mungkin diperoleh dari investasi saham dan berusaha mengetahui apa yang akan terjadi pada investasi saham apabila terjadi perubahan pada faktor lain. Hasil penelitian terhadap 22 sampel LQ 45 dan 14 sampel JII menunjukkan hasil bahwa ada pengaruh positif linier antara risk dengan return. Hasil risk dan return dari LQ 45 serta JII dibandingkan untuk melihat investasi mana yang lebih menguntungkan buat investor. Dari hasil penelitian diketahui bahwa return JII lebih tinggi dibandingkan dengan LQ 45, sehingga rekomendasi yang diberikan adalah sebaiknya investor mulai melihat saham JII sebagai alternatif investasi masa depan.

Erwin (2005) meneliti tentang perbandingan risiko dan tingkat pengembalian komoditi emas dan olein. Populasi yang digunakan adalah harga komoditas berjangka emas dan komoditas berjangka olein. Sedangkan sampel yang digunakan adalah harga akhir (settlement prices) komoditas berjangka emas dan komoditas berjangka olein. Variabel penelitiannya adalah tingkat risiko investasi berjangka dan tingkat pengembalian investase kontrak komoditi olein, emas. Metode expected return digunakan dalam menghitung nilai pengembalian investasi, alat analisis yang digunakan adalah independent sample T-test. Hasil penelitian ini adalah kontrak berjangka komoditi olein memiliki tingkat pengembalian yang kecil dan risikonya besar dibandingkan dengan kontrak berjangka komoditi emas yang memiliki tingkat pengembalian yang lebih besar dan risiko yang lebih kecil pada periode Januari 2003 hingga Juni 2005. Setelah dilakukan uji rata-rata satu arah perbandingan tingkat pengembalian dan risiko kontrak berjangka komoditi olein dan kontrak berjangka komoditi emas memiliki perbedaan yang signifikan secara statistik.

Junanda (2004) melakukan penelitian mengenai analisis perbandingan return reksadana saham dengan IHSG serta konsistensi model pengukuran reksadana saham di Bursa Efek Jakarta. Fokus pengukuran kinerja menggunakan model pengukuran kinerja Treynor, Sharpe dan Jensen. Dalam penelitian tersebut permasalahan adalah apakah ada perbedaan return reksadana saham dengan return pasar, apakah ada perbedaan kinerja reksadana dibandingkan kinerja pasar (IHSG) dengan mengunakan pengukuran kinerja Treynor, Sharpe dan Jansen, serta apakah terdapat perbedaan konsistensi model pengukuran kinerja dari ketiga pengukuran kinerja tersebut. Hasil dari penelitian tersebut adalah tidak ada perbedaan antara return reksadana saham dengan return pasar (IHSG) untuk semua reksadana saham. Model kinerja Treynor dan Jensen mempunyai kinerja yang berbeda dengan IHSG, dengan rata-rata kinerja yang lebih rendah dibandingkan kinerja pasar. Pengujian konsistensi menunjukkan bahwa ketiga model pengukuran kinerja untuk model Treynor dengan model kinerja Jensen tidak ada perbedaan. Sedangkan untuk model Sharpe berbeda dengan model Treynor dan Jensen. 


\section{Pengembangan Hipotesis}

1. Emas memiliki perbedaan risk dan return dibandingkan dengan indeks LQ 45.

2. Emas memiliki perbedaan risk dan return dibandingkan dengan reksadana saham.

3. LQ 45 memiliki perbedaan risk dan return dibandingkan dengan reksadana saham.

4. Dari ketiga instrumen investasi tersebut emas merupakan instrumen investasi yang paling menguntungkan.

\section{METODE PENELITIAN}

Penelitian ini bertujuan untuk membandingkan risk dan return investasi pada tiga instrumen investasi yaitu emas, indeks LQ45 dan reksadana saham.

\section{Sampel Penelitian dan Sumber Data}

Sampel yang digunakan dalam penelitian ini adalah data harga berdasarkan history price dari ketiga instrumen investasi pada emas, indeks LQ45 dan reksadana saham selama periode tahun 1997 hingga tahun 2009. Metode yang digunakan dalam menentukan sampel adalah metode pemilihan sampel non probabilitas dengan kategori Judgement Sampling, yang mempunyai konsep pemilihan sampel berdasarkan penilaian terhadap beberapa karakteristik anggota sampel yang disesuaikan dengan maksud penelitian.

\section{Definisi Operasional Variabel Penelitian}

Definisi operasional variabel diperlukan untuk memperjelas definisi dan memudahkan pengukuran terhadap masing-masing variabel yang digunakan dalam penelitian. Definisi operasional dari masing-masing variabel penelitian ini adalah sebagai berikut:

1. Return adalah imbal hasil dari investasi yang merupakan tujuan dari kegiatan investasi. Menurut Halim (2005: 36), return dapat diukur dengan menggunakan rumus sebagai berikut:

$$
\begin{aligned}
& \mathbf{R}_{\mathbf{X} \mathbf{1}}=\frac{\mathbf{P}_{\mathbf{t}}-\mathbf{P}_{\mathbf{t}-\mathbf{1}}}{\mathbf{P}_{\mathbf{t}-\mathbf{1}}} \\
& \text { Dimana : } \\
& \mathrm{R}_{\mathrm{X} \mathbf{1}} \quad \text { Tingkat pengembalian investasi } \\
& \mathrm{P}_{\mathrm{t}} \quad \text { = Harga tahun sekarang } \\
& \mathrm{P}_{\mathrm{t}-1} \quad=\text { Harga tahun lalu }
\end{aligned}
$$

Rumus tersebut digunakan untuk menghitung return dari ketiga instrumen investasi yang dipilih, yaitu digunakan pada emas, indeks LQ 45 dan reksadana saham. 
2. Variabel Risk, menurut Halim (2005: 42), risiko merupakan besarnya penyimpangan antara tingkat pengembalian yang diharapkan dengan pengembalian yang sebenarnya. Menurut Hartono (2009: 221), risk dapat diukur menggunakan rumus sebagai berikut:

$$
\mathbf{S D}=\sqrt{\frac{\sum_{\mathbf{i}=\mathbf{1}[\mathbf{X}-\mathbf{E}(\mathbf{X} \mathbf{i})]^{2}}^{\mathbf{n}-1}}{1}}
$$

Dimana :

$\begin{aligned} \mathrm{SD} & =\text { Standar Deviasi } \\ \mathrm{Xi} & =\text { nilai ke-i } \\ \mathrm{E}(\mathrm{Xi}) & =\text { nilai eksperimen } \\ \mathrm{n} & =\text { jumlah dari observasi data historis untuk sampel besar dengan } \mathrm{n} \\ & \quad \text { (paling sedikit } 30 \text { observasi) dan untuk sampel kecil digunakan (n-1) }\end{aligned}$ yang dipilih, yaitu digunakan pada emas, indeks LQ 45, dan reksadana saham. Setelah mengetahui variabel risk dan return, digunakan koefisien variasi (coefficient of variation) untuk mempertimbangkan dua faktor tersebut bersamaan. Menurut Hartono (2009: 224), rumus koefisien variasi (coefficient of variation) adalah :

$$
\mathrm{CV}_{\mathrm{i}}=\frac{\text { Risiko }}{\text { Return Ekspektasi }}
$$

Dimana :

$\mathrm{CV}_{\mathrm{i}}=$ coefficient of variation (koefisien variasi) untuk aktiva ke-i.

Dari rumus koefisien variasi (coefficient of variation) dapat diartikan bahwa semakin kecil nilai koefisien variasi semakin baik aktiva tersebut. Semakin kecil koefisien variasi menunjukkan semakin kecil risiko aktiva dan semakin besar return ekspektasinya.

\section{Teknik Analisis Data}

Dalam penelitian komparatif, metode analisis data dan pengujian hipotesis dilakukan dengan cara uji beda mean (compare mean). Compare mean merupakan analisis yang digunakan untuk membandingkan rata-rata dua populasi atau lebih. Menurut Bungin (2005: 185), untuk mengukur hipotesis perbedaan, dilakukan uji untuk mengetahui apakah hipotesis tersebut berbeda secara signifikan atau tidak signifikan. 
Pada penelitian ini, jenis data yang digunakan adalah data rasio dan analisis data yang digunakan adalah one way ANOVA. Sebelum melakukan uji ANOVA, perlu dilakukan terlebih dahulu uji normalitas data dengan menggunakan KolmogorovSmirnov.

\section{HASIL DAN PEMBAHASAN}

Penelitian ini membahas dan membandingkan antara tiga variabel yang berbeda. Masing-masing data dari ketiga variabel tersebut diperoleh dari tiga sumber yang berbeda serta dari perusahaan yang berbeda. Untuk variabel emas, data diperoleh dari data internal perusahaan emas. Untuk data indeks LQ 45, peneliti mendapatkan data dari IDX (Indonesian Stock Exchange). Data reksadana saham, peneliti mendapatkan data dari PT. Danareksa Investment Management.

\section{Deskripsi Statistik}

Pada bagian ini akan dideskripsikan data penelitian yaitu data harga emas, harga indeks saham LQ 45 dan data NAB Danareksa Mawar. Data harga emas tersedia dalam bentuk data bulanan, sedangkan data harga indeks LQ 45 serta data NAB Danareksa Mawar tersedia dalam bentuk data harian. Dari data indeks LQ 45 dan NAB Danareksa Mawar tersebut dianalisis secara harian kemudian dirata - rata untuk mendapatkan data bulanan. Untuk membandingkan mean, nilai tertinggi dan terendah dari return ketiga instrumen investasi, disajikan dalam tabel berikut ini:

\section{Tabel 1. Perbandingan Return Emas, LQ 45, dan Reksadana Mawar Tahun 1997 - 2009}

\begin{tabular}{llclc}
\hline \multicolumn{1}{c}{ Return } & N & Mean & Min & \multicolumn{1}{c}{ Maks } \\
\hline Emas & 13 & 0.013227 & -0.015155 & 0.038717 \\
LQ 45 & 13 & 0.001626 & -0.002883 & 0.015500 \\
Reksadana Mawar & 13 & 0.001359 & 0.003475 & 0.003475 \\
\hline
\end{tabular}

Sumber: Data sekunder yang telah diolah

Data menunjukkan bahwa rata-rata return emas lebih tinggi dibandingkan dengan rata-rata return indeks LQ 45 dan reksadana saham.

\section{Tabel 2. Perbandingan Risk Emas, LQ 45, dan Reksadana Mawar Tahun 1997 - 2009}

\begin{tabular}{ccccc}
\hline Risk & N & Mean & Min & Maks \\
\hline Emas & 13 & 0.064800 & 0.033780 & 0.150846 \\
LQ 45 & 13 & 0.008050 & 0.002654 & 0.046492 \\
Reksadana Mawar & 13 & 0.005573 & 0.002613 & 0.018973 \\
\hline
\end{tabular}

Sumber: Data sekunder yang telah diolah 
Data menunjukkan bahwa emas memiliki rata-rata risk tertinggi apabila dibandingkan dengan indeks LQ 45 dan reksadana saham. Dari analisis koefisien korelasi diketahui bahwa emas memiliki koefisien variasi paling kecil yaitu sebesar 2.605881. Sedangkan reksadana memiliki koefisien variasi sebesar 3.108612, serta indeks LQ 45 memiliki koefisien variasi terbesar yaitu sebesar 4.206448. Dari hasil perhitungan dapat disimpulkan bahwa emas merupakan pilihan investasi yang paling menguntungkan karena semakin kecil koefisien variasi, semakin menguntungkan investasi tersebut.

\section{Uji Asumsi ANOVA Return}

Uji statistik yang digunakan untuk membedakan return dari ketiga sampel yang diuji adalah uji ANOVA. Pada penelitian ini uji normalitas data yang merupakan persyaratan dari uji ANOVA dilakukan karena sampel penelitian kurang dari 30. Uji normalitas yang digunakan adalah Kolmogorov Smirnov. Data dikatakan normal jika signifikansinya lebih dari 0,05 . Berikut hasil uji normalitas data return dari ketiga sampel penelitian.

Tabel 3 menunjukkan bahwa data return dari ketiga sampel berdistribusi normal karena signifikansi seluruh uji lebih besar dari 0,05.

Tabel 3. Uji Normalitas Data pada Return Reksadana Mawar, LQ 45 dan Emas Tahun 1997 - 2009

\begin{tabular}{lccc}
\hline & $\begin{array}{c}\text { Return } \\
\text { reksadana }\end{array}$ & $\begin{array}{c}\text { Return } \\
\text { LQ 45 }\end{array}$ & $\begin{array}{c}\text { Return } \\
\text { emas }\end{array}$ \\
\hline $\mathrm{N}$ & 13 & 13 & 13 \\
Kolmogorov-Smirnov Z & 0.765 & 1.279 & 0.681 \\
Asymp. Sig. (2-tailed) & 0.602 & 0.076 & 0.742 \\
Keterangan & Normal & Normal & Normal \\
\hline
\end{tabular}

Sumber: Data sekunder yang telah diolah

\section{Hasil Pengujian ANOVA Return Pada Seluruh Periode Penelitian}

Hasil uji ANOVA diperoleh tingkat signifikansi 0,001. Nilai signifikansi ini kurang dari 0,05 yang berarti ada perbedaan return antara ketiga sampel yaitu return reksadana saham, indeks LQ 45 dan emas. Untuk mengetahui pasangan kelompok return yang berbeda dilakukan uji lanjut dengan uji LSD (Least Significant Difference). Adapun kriteria pengujian LSD adalah sebagai berikut:

1. Jika signifikansi uji kurang dari atau sama dengan 0,05 maka ada perbedaan antar kelompok return

2. Jika signifikansi uji lebih dari 0,05 maka tidak ada perbedaan antar kelompok return.

Berikut hasil uji LSD antar ketiga kelompok : 
Tabel 4. Tabel Uji Lanjut dengan LSD

\begin{tabular}{llcc}
\hline (I) Type & (J) Type & Mean Difference (I-J) & Sig. \\
\hline NAB & LQ45 & -0.00027069 & 0.936 \\
& EMAS & -0.01186792 & 0.001 \\
LQ45 & NAB & 0.00027069 & 0.936 \\
& EMAS & -0.01159723 & 0.001 \\
EMAS & NAB & 0.01186792 & 0.001 \\
& LQ45 & 0.01159723 & 0.001 \\
\hline
\end{tabular}

Sumber: Data sekunder yang telah diolah

Dari Tabel 4 menunjukkan bahwa nilai perbedaan mean tertinggi pada kelompok emas dan indeks LQ 45 yaitu 0.01186792. Sedangkan antara emas dengan reksadana sebesar 0.01159723 dan nilai perbedaan mean terendah antara reksadana dengan indeks LQ 45 yaitu 0.00027069.

Nilai signifikansi antara return reksadana dengan return Indeks LQ 45 adalah 0.936 yang berarti tidak ada perbedaan return reksadana dengan return LQ 45. Nilai signifikansi antara return reksadana dengan emas adalah 0.001 yang berarti ada perbedaan return reksadana dengan return emas. Nilai signifikansi antara return Indeks LQ 45 dengan emas adalah 0.001 yang berarti ada perbedaan return Indeks LQ 45 dengan return emas. Hasil menunjukkan bahwa return emas lebih tinggi dibandingkan dengan return reksadana dan indeks LQ45.

\section{Uji ANOVA Risk Reksadana Mawar, LQ 45 dan Emas}

Uji statistik yang digunakan untuk membedakan risiko dari ketiga sampel tersebut adalah uji ANOVA. Pada penelitian ini uji normalitas data yang merupakan persyaratan dari uji ANOVA dilakukan karena sampel penelitian kurang dari 30. Uji normalitas yang digunakan adalah Kolmogorov Smirnov. Data dikatakan normal jika signifikansinya lebih dari 0,05 . Berikut hasil uji normalitas data risiko dari ketiga sampel penelitian:

Tabel 5. Uji Normalitas Data pada Risk Reksadana Mawar, LQ 45 dan Emas Tahun 1997 - 2009

\begin{tabular}{lccc}
\hline & $\begin{array}{c}\text { Risiko } \\
\text { reksadana }\end{array}$ & $\begin{array}{c}\text { Risiko } \\
\text { LQ 45 }\end{array}$ & $\begin{array}{c}\text { Risiko } \\
\text { emas }\end{array}$ \\
\hline $\mathrm{N}$ & 13 & 13 & 13 \\
Kolmogorov-Smirnov Z & 1.069 & 0.754 & 0.861 \\
Asymp. Sig. (2-tailed) & 0.203 & 0.621 & 0.449 \\
Keterangan & Normal & Normal & Normal \\
\hline
\end{tabular}

Sumber: Data sekunder yang telah diolah 
Tabel 5 menunjukkan bahwa data risiko dari ketiga sampel berdistribusi normal karena signifikansi seluruh uji lebih besar dari 0,05.

\section{Hasil Pengujian ANOVA Risk Pada Seluruh Periode Penelitian}

Hasil uji ANOVA pada risiko dari reksadana, LQ 45 dan emas diperoleh hasil sebagai berikut :

\section{Tabel 6. Tabel Uji F ANOVA pada Data Risiko}

\begin{tabular}{|c|c|c|c|c|c|}
\hline & $\begin{array}{l}\text { Sum of } \\
\text { Squares }\end{array}$ & $\mathrm{df}$ & Mean Square & $\mathrm{F}$ & Sig. \\
\hline Between Groups & .014 & 2 & .007 & 67.346 & .000 \\
\hline Within Groups & .004 & 36 & .000 & & \\
\hline Total & .017 & 38 & & & \\
\hline
\end{tabular}

Sumber: Data sekunder yang telah diolah

Hasil uji ANOVA diperoleh tingkat signifikansi 0,000. Nilai signifikansi ini kurang dari 0,05 yang berarti ada perbedaan risiko antara ketiga sampel yaitu risiko reksadana saham, indeks LQ 45 dan emas. Oleh karena ada perbedaan maka sekurang-kurangnya ada satu pasang kelompok risiko yang berbeda. Untuk mengetahui pasangan kelompok risiko yang berbeda dilakukan uji lanjut dengan uji LSD (Least Significant Difference). Berikut hasil uji LSD antar ketiga kelompok.

Tabel 6 menunjukkan bahwa nilai perbedaan mean tertinggi pada kelompok emas dan LQ 45 yaitu 0.03983454. Sedangkan antara emas dengan reksadana sebesar 0.03947715. dan nilai perbedaan mean terendah antara reksadana dengan LQ 45 yaitu 0.00035738. Nilai signifikansi antara risiko reksadana dengan risiko Indeks LQ 45 adalah 0.928 yang berarti tidak ada perbedaan risiko reksadana dengan risiko LQ 45. Nilai signifikansi antara risiko reksadana dengan emas adalah 0.000 yang berarti ada perbedaan risiko reksadana dengan risiko emas. Nilai signifikansi antara risiko Indeks LQ 45 dengan emas adalah 0.000 yang berarti ada perbedaan risiko Indeks LQ 45 dengan risiko emas.

\section{Tabel 7. Tabel Uji Lanjut dengan LSD pada Data Risiko}

\begin{tabular}{llcc}
\hline (I) Type & (J) Type & Mean Difference (I-J) & Sig. \\
\hline NAB & LQ45 & 0.00035738 & 0.928 \\
& EMAS & -0.03947715 & 0.000 \\
\multirow{2}{*}{ LQ45 } & NAB & -0.00035738 & 0.928 \\
& EMAS & -0.03983454 & 0.000 \\
EMAS & NAB & 0.03947715 & 0.000 \\
& LQ45 & 0.03983454 & 0.000 \\
\hline
\end{tabular}

Sumber: Data sekunder yang telah diolah 


\section{SIMPULAN DAN KETERBATASAN PENELITIAN}

\section{Simpulan}

1. Hasil penelitian membuktikan bahwa hipotesis pertama pada penelitian ini diterima. Dari hasil pengujian uji F ANOVA dan uji lanjut dengan LSD terdapat perbedaan yang signifikan risk dan return emas dengan risk dan return indeks LQ 45. Terbukti bahwa return emas lebih tinggi dibandingkan dengan return indeks LQ 45 dari rata-rata yang nilainya sebesar $1.32 \%$ : 0.16\%. Sedangkan untuk nilai risk, emas memiliki rata-rata risk yang lebih tinggi apabila dibandingkan dengan indeks LQ 45, yaitu sebesar 6.48\%: 0.8\%.

2. Hasil penelitian membuktikan bahwa hipotesis kedua pada penelitian ini diterima. Dari hasil pengujian uji F ANOVA dan uji lanjut dengan LSD terdapat perbedaan yang signifikan return emas dengan return reksadana saham. Terbukti bahwa return emas lebih tinggi dibandingkan dengan return reksadana saham dari rata-rata yang nilainya sebesar $1.32 \%: 0.13 \%$. Sedangkan untuk nilai risk, emas memiliki rata-rata risk yang lebih tinggi apabila dibandingkan dengan reksadana saham, yaitu sebesar $6.48 \%: 0.56 \%$.

3. Hasil penelitian membuktikan bahwa hipotesis ketiga pada penelitian ini diterima. Dari hasil pengujian uji F ANOVA dan uji lanjut dengan LSD terdapat perbedaan return indeks LQ 45 dengan return reksadana saham, namun perbedaan tersebut tidak signifikan. Terbukti bahwa return indeks LQ 45 lebih tinggi dibandingkan dengan return reksadana saham dari rata-rata yang nilainya sebesar $0.16 \%$ : $0.13 \%$ namun tidak signifikan. Sedangkan untuk nilai risk, indeks LQ 45 memiliki rata-rata risk yang lebih tinggi apabila dibandingkan dengan reksadana, yaitu sebesar $0.8 \%: 0.56 \%$, namun perbedaan tersebut tidak signifikan.

4. Hasil penelitian membuktikan bahwa hipotesis keempat pada penelitian ini diterima. Dapat diketahui bahwa emas memiliki koefisien variasi paling kecil Sedangkan reksadana saham memiliki koefisien variasi kedua terkecil, serta indeks LQ 45 memiliki koefisien variasi terbesar. Dengan demikian emas menjadi pilihan pertama sebagai sarana investasi paling menguntungkan, disusul dengan reksadana saham dan yang terakhir adalah indeks LQ 45.

\section{Keterbatasan Penelitian}

Pemilihan instrumen investasi yang dibandingkan pada penelitian ini cukup terbatas, padahal terdapat instrumen investasi yang lain seperti obligasi, valas, dan barang-barang komoditas yang lain seharusnya dapat pula diteliti dalam penelitian. Namun oleh karena keterbatasan data dan waktu maka instrumen-instrumen pembanding lainnya tersebut tidak ditambahkan.

Hasil penelitian ini membuktikan bahwa semua hipotesis pada penelitian ini diterima. Namun dari hasil penelitian seharusnya dapat ditambahkan analisis business cycle untuk mengetahui trend kenaikan dan penurunan harga untuk masing-masing instrumen penelitian yang diteliti. Namun oleh karena terbatasnya waktu, analisis ini tidak dilakukan. Penelitian ini juga tidak menyertakan teori portofolio, dimana suatu 
investasi dapat terdiri dari banyak instrument investasi berdasarkan porsi masingmasing. Teori portofolio penting dalam menyiasati kegagalan suatu investasi tertentu, seperti kata pepatah "Jangan menaruh telur dalam satu keranjang yang sama". Namun oleh karena keterbatasan waktu penelitian, maka analisis ini tidak ditambahkan. 


\section{DAFTAR PUSTAKA}

Bungin, Burhan. 2010. Metodologi Penelitian Kuantitatif. Jakarta: Kencana Prenada Media Group

Erwin. 2005. Analisis Perbandingan Investasi Kontrak Berjangka Olein dengan Kontrak Berjangkan Komoditi Emas Ditinjau dari Risiko dan Tingkat Pengembaliannya (expected return). Skripsi. Universitas Widyatama Bandung

Ghozali, Imam. 2008. Aplikasi Analisis Multivariate Dengan Program SPSS. Semarang: Badan Penerbit Universitas Diponegoro

Hakim, Abdul. 2000. Statistik Induktif Untuk Ekonomi dan Bisnis. Yogyakarta: Penerbit Ekonisia

Halim, Abdul. 2005. Analisis Investasi. Jakarta: Salemba Empat

Hartono, Jogiyanto. 2009. Teori Portofolio dan Analisis Investasi. Yogyakarta: YOGYAKARTA

Iman, novie. 2009. Investasi emas. Jakarta: Daras books

Junanda. 2004. Analisis Perbandingan Return Reksadana Saham Dengan IHSG Serta Konsistensi Model Pengukuran Reksadana Saham di Bursa Efek. Tesis. Program Studi Magíster Manajemen Universitas Diponegoro Semarang

Kontan. 2009. Kenaikan Produksi Tak Pengaruhi Harga Emas. http://www.kontan.co.id/index.php/investasi/news/22292/Kenaikan-Produksi-

Tak-Pengaruhi-Harga-Emas. 29 Juni 2010

Kuncoro, Mudrajad. 2003. Metode Riset Untuk Bisnis \& Ekonomi. Jakarta: Penerbit Erlangga

Oei, Istijanto. 2009. Kiat Investasi Valas, Emas, Saham. Jakarta: Gramedia Pustaka Utama

Palaloi, Mohamad Ihsan dkk. 2006. Kemilau Investasi Emas. Jakarta: Science Research Foundation

Palaloi, Mohamad Ihsan. 2008. Menghadapi Krisis dengan Investasi Emas. http://www.investasiemas.info/index.php?mod=index\&act=viewNews\&id=183. 24 Agustus 2010.

Pratomo, Eko Priyo dan Nugraha, Ubaidillah. 2005. Reksadana Solusi Perencanaan Investasi di Era Modern. Jakarta: Gramedia Pustaka Utama

Prasetyo, Bambang dan Jannah, Lina Miftahul. 2005. Metode Penelitian Kuantitatif. Jakarta: Raja Grafindo Persada

Raharjo, Sapto. 2006. Panduan Investasi Reksadana. Jakarta: Elex Media Komputindo

Riessa, Syarifah Farah. 2006. Kajian Perbandingan Risk dan Return Pada Saham LQ 45 dan Jakarta Islamic Indeks Dengan Pendekatan CAPM. Tesis. Program Studi Magíster Manajemen Facultas Ekonomi Universitas Indonesia Jakarta.

Robandi, Imam. 2008. Becoming the Winner Riset, Menulis Ilmiah, Publikasi Ilmiah, dan Presentasi. Yogyakarta: ANDI

Rochaety, Eti dan Tresnati, Ratih. 2007. Kamus Istilah Ekonomi. Jakarta: Bumi Aksara 
Saltian, Yoga. 2006. Analisis Tingkat Perbandingan Risiko dan Pengembalian Reksadana Syariah dan Reksadan Konvensional. Skripsi. Universitas Islam Indonesia Yogyakata.

Sugiyono.2008. Metode Penelitian Kuantitatif Kualitatif dan R\&D. Bandung: Alfabeta

Sumadji,dkk. 2006. Kamus Ekonomi Edisi Lengkap. Jakarta: Wacana Intelektual

SWA. 2007. Instrumen Investasi Paling Hot 2007. http://swa.co.id/2007/01/instrumen-investasi-paling-hot-2007/. 29 Juni 2010

Widya. 2001. Analisis Pengaruh Likuiditas, Leverage, Aktivitas dan Pertumbuhan Ukuran Perusahaan Terhadaap Return on Investment Perusahaan Makanan dan Minuman yang Go Public di Indonesia. Tesis. Pascasarjana Universitas Airlangga Surabaya

Wijaya, Toni. 2009. Analisis Data Penelitian Menggunakan SPSS. Yogyakarta: Universitas Atma Jaya Yogyakarta 